\title{
Demonstration of the BioBaler harvesting system for collection of small-diameter woody biomass
}

\section{December 2011}

\author{
Prepared by \\ Matt Langholtz ${ }^{1}$, Kevin Caffrey ${ }^{2}$, Elliott Barnett ${ }^{3}$, Erin Webb ${ }^{1}$, M. Wesley \\ Brummette $^{2}$, Mark Downing ${ }^{1}$ \\ ${ }^{1}$ Environmental Sciences Division \\ 2 ORISE Student Programs \\ ${ }^{3}$ Utilities Division (Strata-G)
}

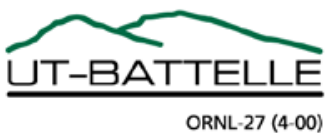




\title{
DOCUMENT AVAILABILITY
}

Reports produced after January 1, 1996, are generally available free via the U.S. Department of Energy (DOE) Information Bridge.

Web site http://www.osti.gov/bridge

Reports produced before January 1, 1996, may be purchased by members of the public from the following source.

\author{
National Technical Information Service \\ 5285 Port Royal Road \\ Springfield, VA 22161 \\ Telephone 703-605-6000 (1-800-553-6847) \\ TDD 703-487-4639 \\ Fax 703-605-6900 \\ E-mail info@ntis.gov \\ Web site http://www.ntis.gov/support/ordernowabout.htm
}

Reports are available to DOE employees, DOE contractors, Energy Technology Data Exchange (ETDE) representatives, and International Nuclear Information System (INIS) representatives from the following source.

Office of Scientific and Technical Information

P.O. Box 62

Oak Ridge, TN 37831

Telephone 865-576-8401

Fax 865-576-5728

E-mail reports@osti.gov

Web site http://www.osti.gov/contact.html

This report was prepared as an account of work sponsored by an agency of the United States Government. Neither the United States Government nor any agency thereof, nor any of their employees, makes any warranty, express or implied, or assumes any legal liability or responsibility for the accuracy, completeness, or usefulness of any information, apparatus, product, or process disclosed, or represents that its use would not infringe privately owned rights. Reference herein to any specific commercial product, process, or service by trade name, trademark, manufacturer, or otherwise, does not necessarily constitute or imply its endorsement, recommendation, or favoring by the United States Government or any agency thereof. The views and opinions of authors expressed herein do not necessarily state or reflect those of the United States Government or any agency thereof. 
Environmental Sciences Division

\title{
DEMONSTRATION OF THE BIOBALER HARVESTING SYSTEM FOR COLLECTION OF SMALL-DIAMETER WOODY BIOMASS
}

\author{
Matt Langholtz, Kevin Caffrey, Elliott Barnett, Erin Webb, M. Wesley Brummette, Mark Downing
}

Date Published: December 2011

Prepared by

OAK RIDGE NATIONAL LABORATORY

Oak Ridge, Tennessee 37831-6283

managed by

UT-BATTELLE, LLC

for the

U.S. DEPARTMENT OF ENERGY

under contract DE-AC05-00OR22725 



\section{CONTENTS}

Table of Contents

Page

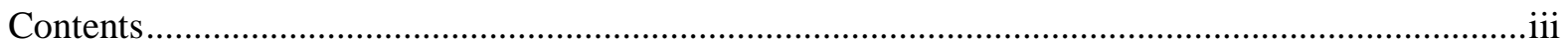

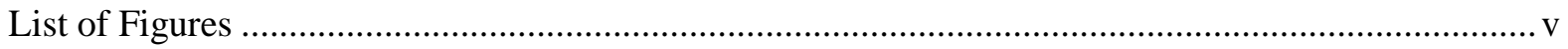

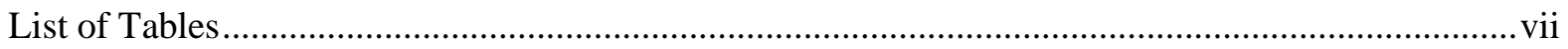

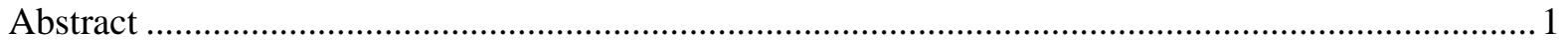

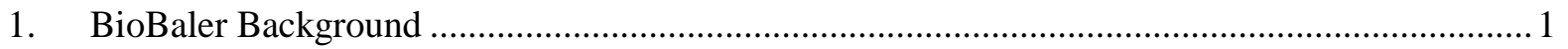

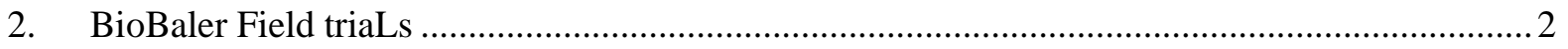

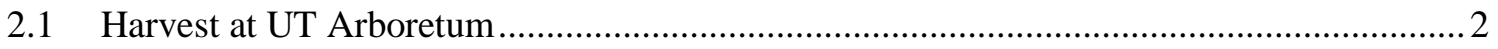

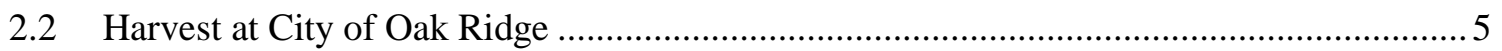

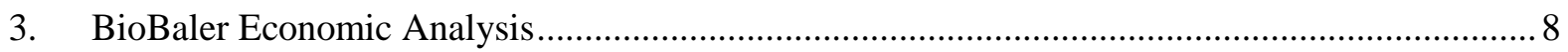

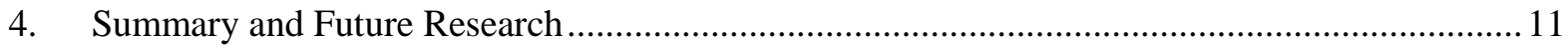

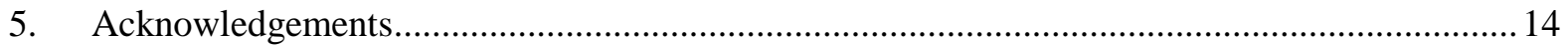

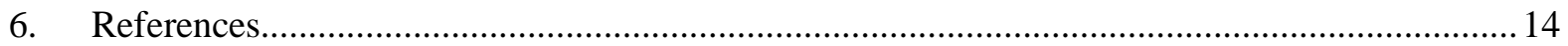

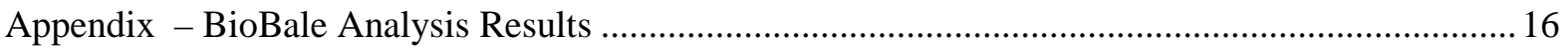





\section{LIST OF FIGURES}

Figure

Page

Figure 1. Anderson Group BioBaler brought to Oak Ridge by Tom King of Super Trak,

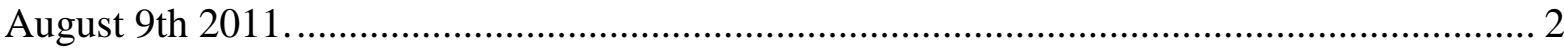

Figure 2. Field trial of the BioBaler at Site \#3 of the UT Arboretum on August 9th, 2011.... 3

Figure 3. Sites \#1 (above) and \#2 of the BioBaler test harvest at the UT Arboretum on August 9th, 2011. These sites contained mostly herbaceous material and were not effectively baled. 3

Figure 4. Site \#3 (0.5”-4" woody vegetation) of the BioBaler test harvest at the UT Arboretrum on August $9^{\text {th }}$, 2011. This site was effectively baled. ....................................... 3

Figure 5. Field day demonstration of the BioBaler at the UT Arboretum, August $10^{\text {th }} 2011.4$

Figure 6. Bales from the UT Arboretum and the City of Oak Ridge after 30 days................ 4

Figure 7. Weighing the bales on a portable digital scale. Tissue samples were taken from each bale for moisture content and proximate and ultimate analysis. .................................. 5

Figure 8. BioBaler harvest trial site at the City of Oak Ridge........................................... 6

Figure 9. City of Oak Ridge trail site: widely-spaced clumps of mature trees with thick

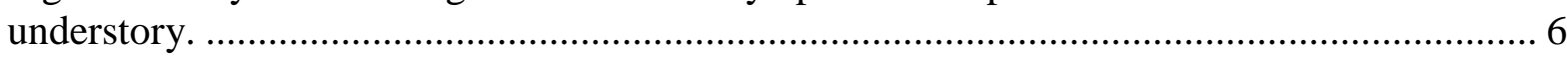

Figure 10. During (top) and after (bottom) bailing operations at the City of Oak Ridge....... 7

Figure 11. Underbrush removed following treatment with the BioBaler. ............................ 7

Figure 12. Baling cost (\$/green ton) as a function of production rate (bales/hour). Assumptions shown in Table 6 and Table 7.

Figure 13. Sensitivity of BioBale harvest and forwarding cost to diesel cost assuming 900 green $\mathrm{lbs} / \mathrm{bale}$ (37.5\% MC), and a harvest rate of 15 bales/hour. A $\$ 1.00 /$ gallon increase in the price of diesel translates to a $6 \%$ increase in the harvest and forwarding cost. ............... 11

Figure 14. BioBaler demonstration participants from ORNL, the USDA Forest Service, TN Division of Forestry, Genera Energy, the University of Tennessee, and Domtar Paper. August 10th, 2011 at the UT Arboretum. 



\section{LIST OF TABLES}

\section{Table}

Page

Table 1. Bale weights observed on September 9th, 2011, 30 days after harvest. Bales were harvested at the University of Tennessee Forest Resources Research and Education Center on August 10th, 2011.

Table 2. Bale weights observed on September 9th, 2011, 29 days after harvest. Bales were harvested from city land at the City of Oak Ridge on August 11th, 2011.

Table 3. Owning and operating costs for four pieces of equipment needed in a BioBale harvesting operation (provided by Anderson Group)...................................................... 10

Table 4. Combined operational costs and total harvest costs to field side (\$/ton)................ 11

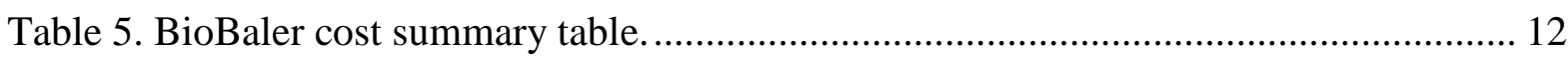

Table 6. Analysis results of BioBale biomass samples. Bales were harvested on August $10^{\text {th }}$, samples were taken on September $9^{\text {th }}$, sent to Twin Ports Testing on September $12^{\text {th }}$, and processed on September $14^{\text {th }}$, 2011. Samples A1-A5 were taken at the UT Arboretum, while samples C1-C5 were taken from the City of Oak Ridge. 



\begin{abstract}
As part of a project to investigate sustainable forest management practices for producing wood chips on the Oak Ridge Reservation (ORR) for the ORNL steam plant, the BioBaler was tested in various Oak Ridge locations in August of 2011. The purpose of these tests and the subsequent economic analysis was to determine the potential of this novel woody biomass harvesting method for collection of small-diameter, low value woody biomass. Results suggest that opportunities may exist for economical harvest of low-value and "liability" or negative-cost biomass. (e.g., invasives). This could provide the ORR and area land managers with a tool to produce feedstock while improving forest health, controlling problem vegetation, and generating local employment.
\end{abstract}

\title{
1. BIOBALER BACKGROUND
}

During the summer of 2011, funding was provided as part of the ORNL Operations Improvement Program to consider the potential for applying sustainable forest management practices on the Oak Ridge Reservation (ORR) for supplying wood chips to the ORNL biomass steam plant (anticipated construction completion in early 2012). As a supporting activity, the BioBaler (http://www.grpanderson.com/en/biomass/biobaler-system), a machine designed to harvest small-diameter woody biomass, was tested in various locations around the city of Oak Ridge. The BioBaler was designed by the Anderson Group (Chesterville, Quebec) and is manufactured by SuperTrak (Punta Gorda, FL).

In preparation for a pre-commercial thinning trial of overstocked stands on the ORR, we interviewed local timber harvesters. In these discussions it became apparent that there is a lack of harvesting equipment capable of cutting and collecting trees less than 6" diameter at breast height $(\mathrm{DBH})$, both locally and regionally. As with other areas of the country, smalldiameter woody biomass represents an opportunity to produce fuel while improving forest health and reducing fire risk, yet presents a mechanical and logistical challenge for economically viable harvesting. One innovative piece of equipment designed to address this niche is the BioBaler produced by Anderson Group Company and marketed by Supertrak (Figure 1).

Machinery like the BioBaler can increase land managers' options for vegetation control while providing a bioenergy feedstock. The BioBaler is a specialized harvesting and baling machine designed to harvest woody material between 0.5 in and 4 in diameter. It is a pullbehind bailer requiring a tractor with 160 PTO horsepower. Self-propelled units are in development. It has been used to harvest willow, poplar, eucalyptus, pine and other woody material, and has been applied to harvest short-rotation woody crops, thin stands to improve tree growth, reduce fire risk, remove orchard prunings, and clear abandoned fields and rightof-ways.

The BioBaler cuts and compacts biomass into dense round bales. Bales can then be collected on site at any time after harvest or can be stored in the field for future use. Bale storage facilitates drying, with moisture content decreasing from $50 \%$ to about $25 \%$ in $4-6$ weeks depending on weather conditions. As with herbaceous bales, bale storage life and maintenance of dry matter and Btu content is enhanced through decreased moisture content 
and improved aeration as compared to storage in piles. Field-side storage can reduce the need for on-site storage area while providing a buffer during supply disruptions. We hypothesized that a BioBaler could be applied to a variety of land-management activities on the ORR while providing feedstock to the Steam Plant. Here we evaluate BioBaler application, productivity, and cost in Oak Ridge, TN.

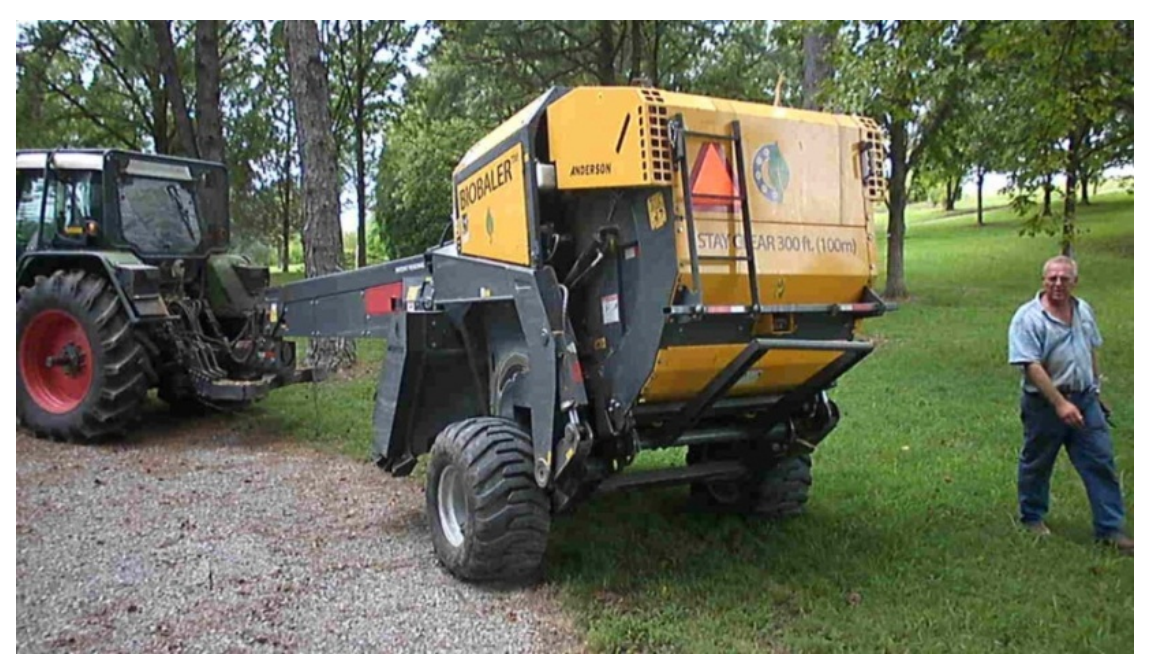

Figure 1. Anderson Group BioBaler brought to Oak Ridge by Tom King of Super Trak, August 9th 2011.

\section{BIOBALER FIELD TRIALS}

\subsection{HARVEST AT UT ARBORETUM}

To evaluate the potential to control invasive plants and improve forest health while providing feedstock for the steam plant, field harvesting trials with the BioBaler were conducted in the Oak Ridge area at two locations over three days. On August $9^{\text {th }}$, 2011 Tom King of Super Trak and Jose Hernandez of Anderson Group met with Matt Langholtz of ORNL and Richard Evans of UT at the University of Tennessee Forest Resources Research and Education Center (Arboretum). Trials were performed on three sites at the Arboretum. Sites \#1 and \#2 were powerline right-of-ways with herbaceous growth about 6 feet tall after two years. The BioBaler effectively cut this material down but failed to collect it in bales, as it was generally less than 0.5 inches in diameter. Site \#3 was approximately 0.7 acres of densely-stocked four-year-old woody regeneration approximately 0.5 inch to 4 inches in diameter (Figure 2). The BioBaler was shown to be effective at collecting and baling material from this site, which was selected for field demonstration the following day. 


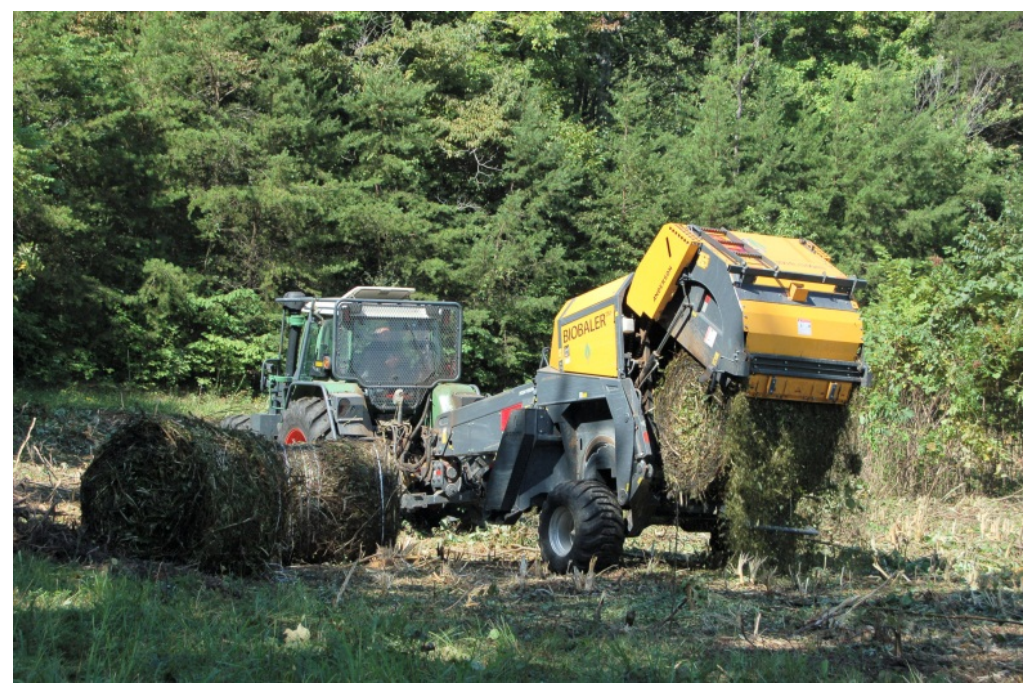

Figure 2. Field trial of the BioBaler at Site \#3 of the UT Arboretum on August 9th, 2011.

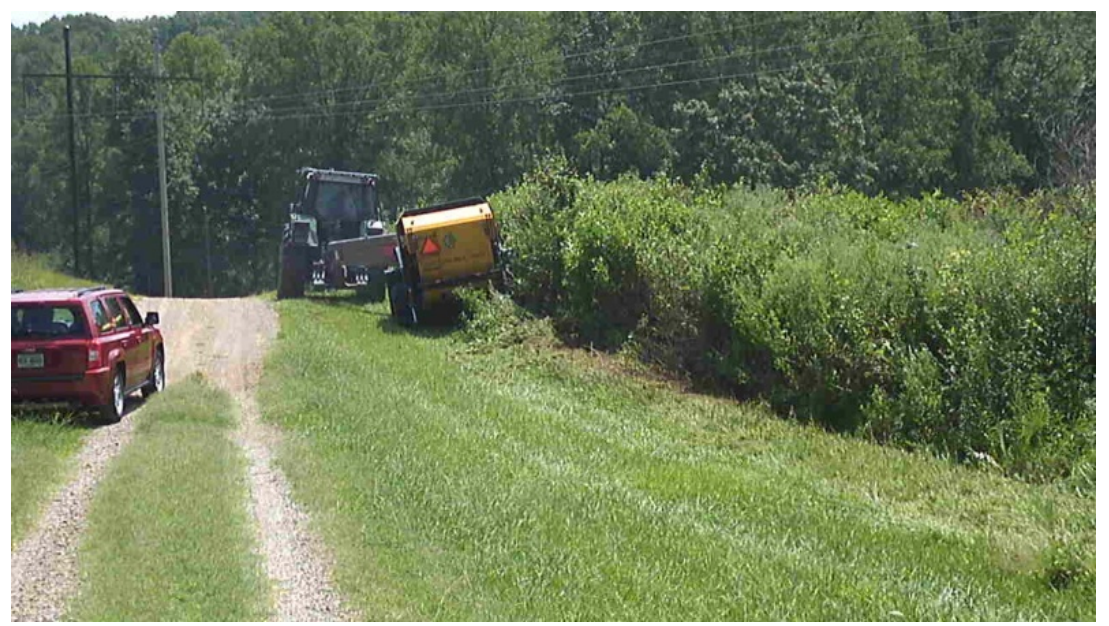

Figure 3. Sites \#1 (above) and \#2 of the BioBaler test harvest at the UT Arboretum on August 9th, 2011. These sites contained mostly herbaceous material and were not effectively baled.

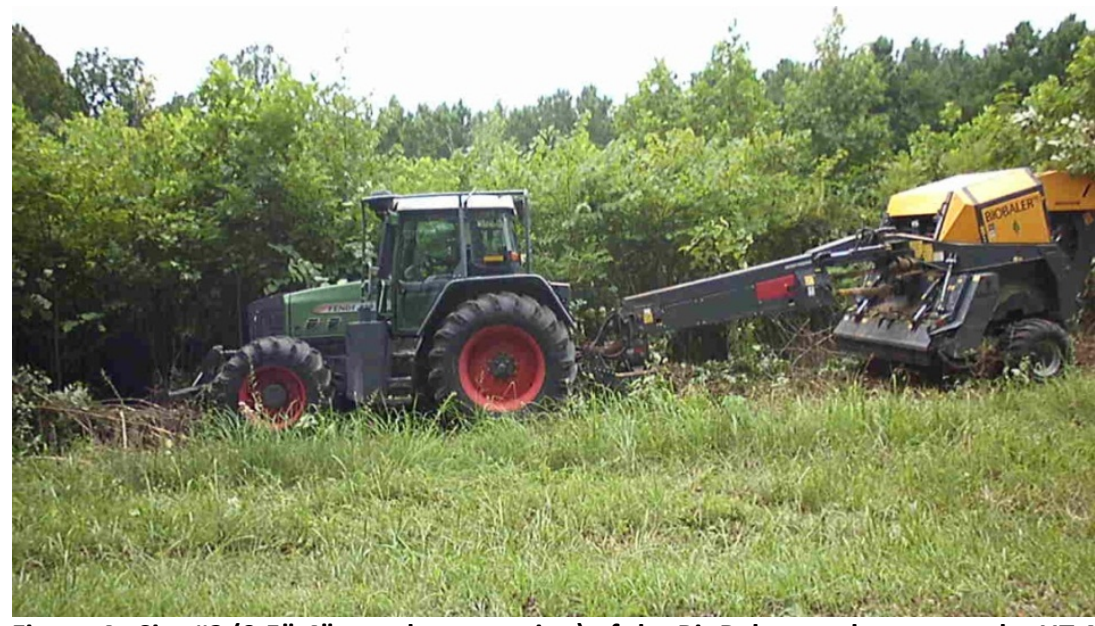

Figure 4. Site $\# 3\left(0.5 "-4\right.$ " woody vegetation) of the BioBaler test harvest at the UT Arboretrum on August $9^{\text {th }}, 2011$. This site was effectively baled.

On August 10th, 2011 a field day was held at the UT Arboretum to foster information 
exchange about the BioBaler. Over thirty participants from ORNL, the USDA Forest Service, TN Division of Forestry, Genera Energy, the University of Tennessee, and Domtar Paper attended the event, as well as local media. The program explored BioBaler background, application, operation, experiences, and economics. The group was shown the results from the previous day's trials on sites \#1 and \#2, and an effective harvest of biomass with the BioBaler was demonstrated for the group on site \#3 (Figure 5). Five bales (averaging 534 dry lb 30 days after harvest) were harvested at a rate of 5-8 minutes per bale or 7-12 bales per hour. The small plot size required frequent machine turns, which reduced the rate of bale production. It was estimated that the same conditions on a larger site could produce approximately 10-15 bales per hour. Bales were weighed after 30 days (Figure 7) with results in Table 1. Tissue samples were taken on September $9^{\text {th }}, 2011$ and shipped to Twin Ports Testing of Superior, WI for analysis. Proximate and ultimate analysis results are shown in the appendix. Moisture contents of samples from the ten bales ranged from $26 \%$ $46 \%$, averaged $37.5 \%$, and were not significantly different between the two sites.

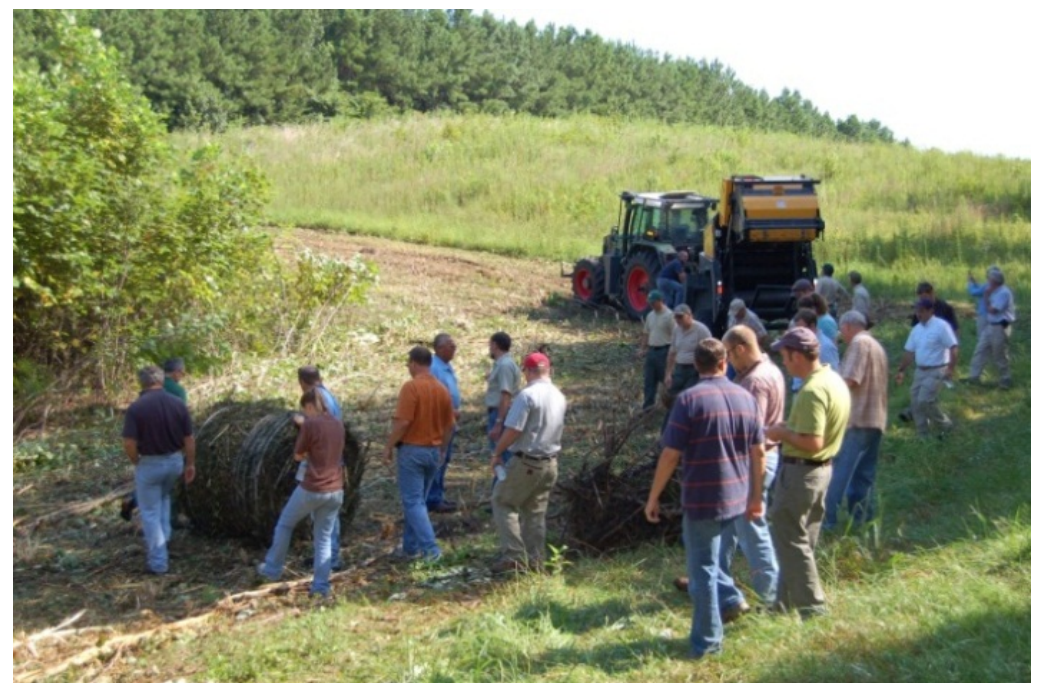

Figure 5. Field day demonstration of the BioBaler at the UT Arboretum, August $10^{\text {th }} 2011$.

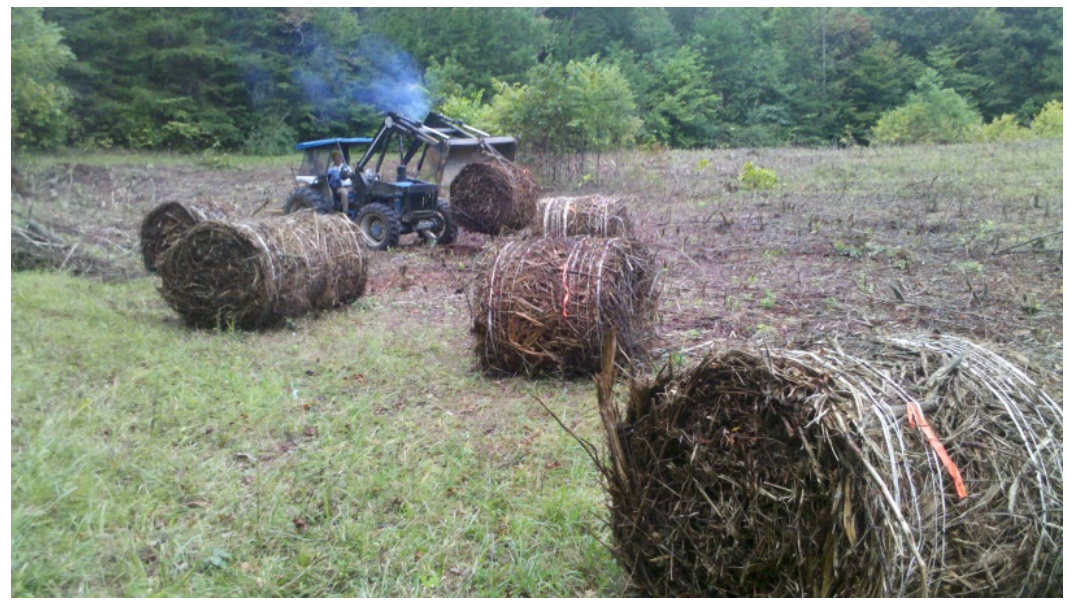

Figure 6. Bales from the UT Arboretum and the City of Oak Ridge after 30 days. 


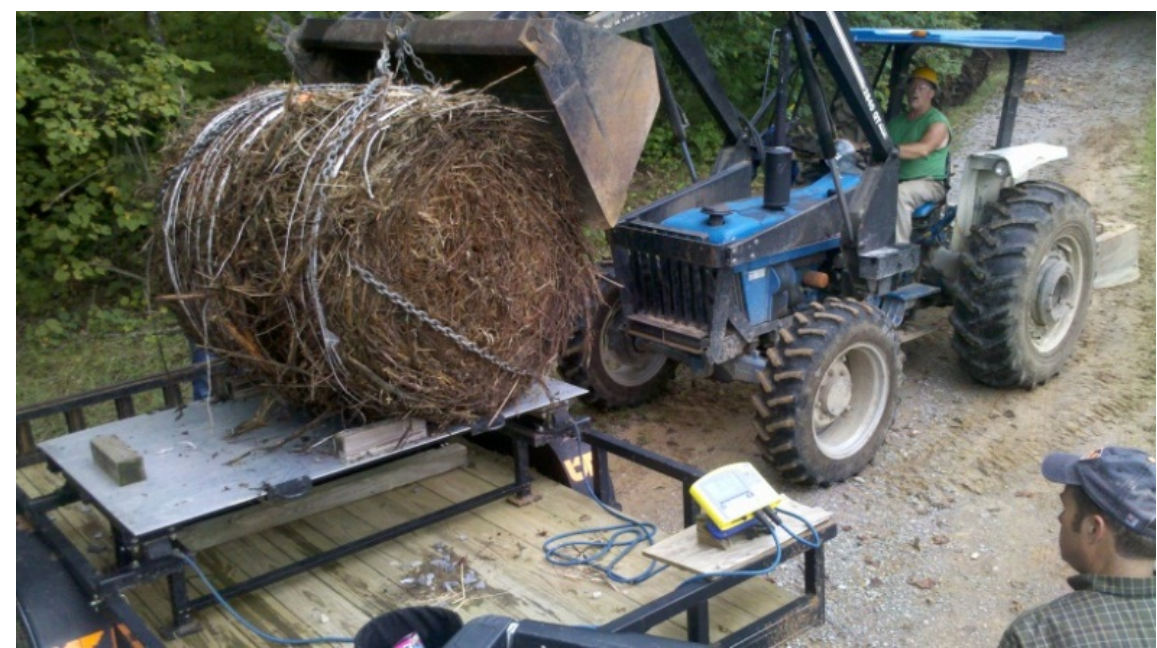

Figure 7. Weighing the bales on a portable digital scale. Tissue samples were taken from each bale for moisture content and proximate and ultimate analysis.

Table 1. Bale weights observed on September 9th, 2011, 30 days after harvest. Bales were harvested at the University of Tennessee Forest Resources Research and Education Center on August 10th, 2011.

\begin{tabular}{ccc}
\hline Bale & Green lbs & $\begin{array}{c}\text { Dry lbs } \\
\text { (moisture content avg 37.5\%, } \mathrm{n}=5 \text { ) }\end{array}$ \\
\hline 1 & 910 & 569 \\
2 & 872 & 545 \\
3 & 672 & 420 \\
4 & 920 & 575 \\
5 & 898 & 561 \\
Average & 854 & 534 \\
\hline
\end{tabular}

\subsection{HARVEST AT CITY OF OAK RIDGE}

To explore potential application of the biobaler under different field conditions, a field trial was conducted on the $3^{\text {rd }}$ day in collaboration with the City of Oak Ridge Parks and Recreation. Josh Collins of the City of Oak Ridge selected a site of about 10 acres in South Oak Ridge off Tuskegee Drive (Figure 8). The Oak Ridge Police Department requested this site be cleared of understory vegetation to facilitate law enforcement by reducing vegetation that provides concealment. The site was characterized as approximately 10 acres of widelyspaced clumps of mature trees with thick undergrowth of mixed hardwoods and vines (Figure 9). Following treatment (Figure 10) underbrush was removed leaving widely-spaced trees (Figure 11Figure 11). Dispersed harvesting locations, the need for frequent turns around trees, and down time caused by urban debris buried in the underbrush reduced the bale production rate. Five bales were harvested in about 2 hours with bale weights shown in Table 2. Bales harvested from the City of Oak Ridge contained larger-diameter material and on average were about 100 lbs heaver (green-weight basis as weighed on September $9^{\text {th }}$, 2011) than the bales from the University of Tennessee Forest Resources.

While harvest rate at the City of Oak Ridge was probably too low to be economically viable (see "BioBaler Economic Analysis" below) it raises the question of the value of alternative objectives. For example, both the City of Oak Ridge and the Tennessee Valley Authority are 
contracting with conventional equipment to clear the type of debris that was harvested by the BioBaler. These types of payments for vegetation control could offset harvest costs and reduce feedstock price.

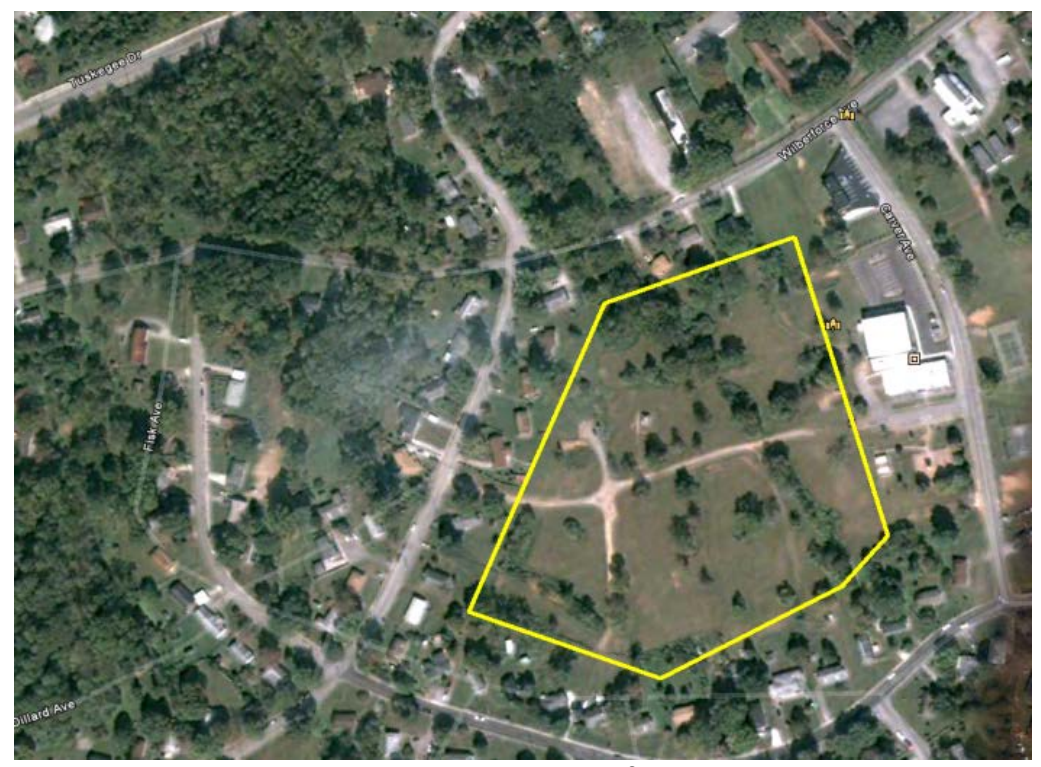

Figure 8. BioBaler harvest trial site at the City of Oak Ridge.

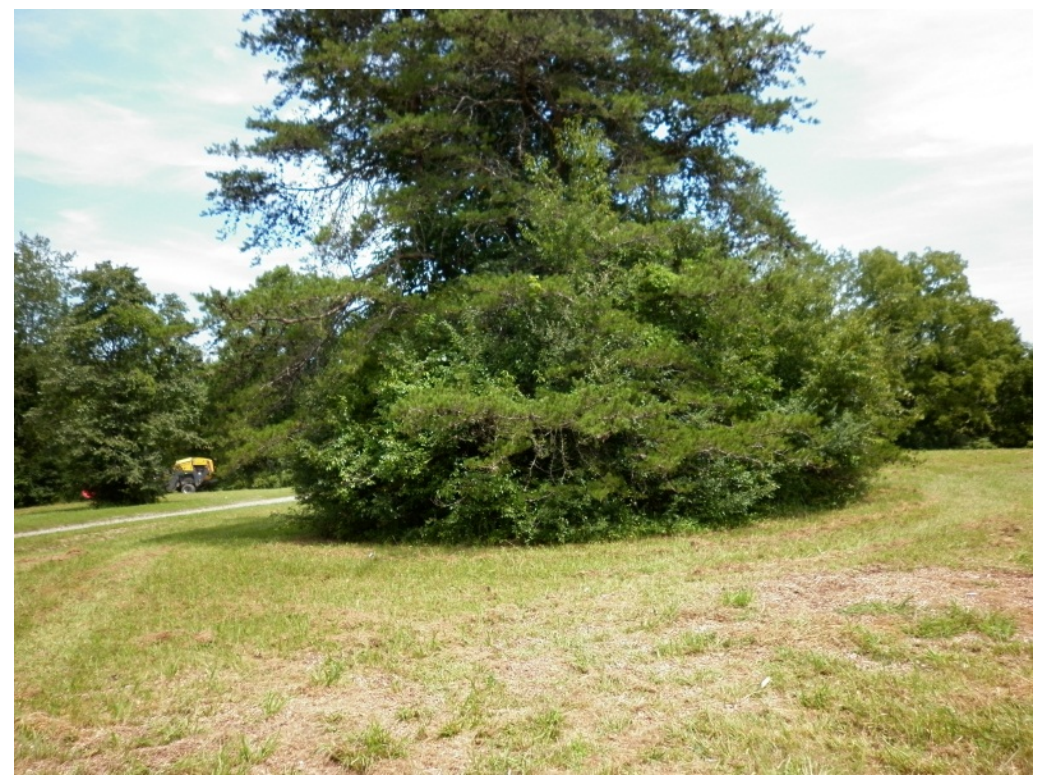

Figure 9. City of Oak Ridge trail site: widely-spaced clumps of mature trees with thick understory. 


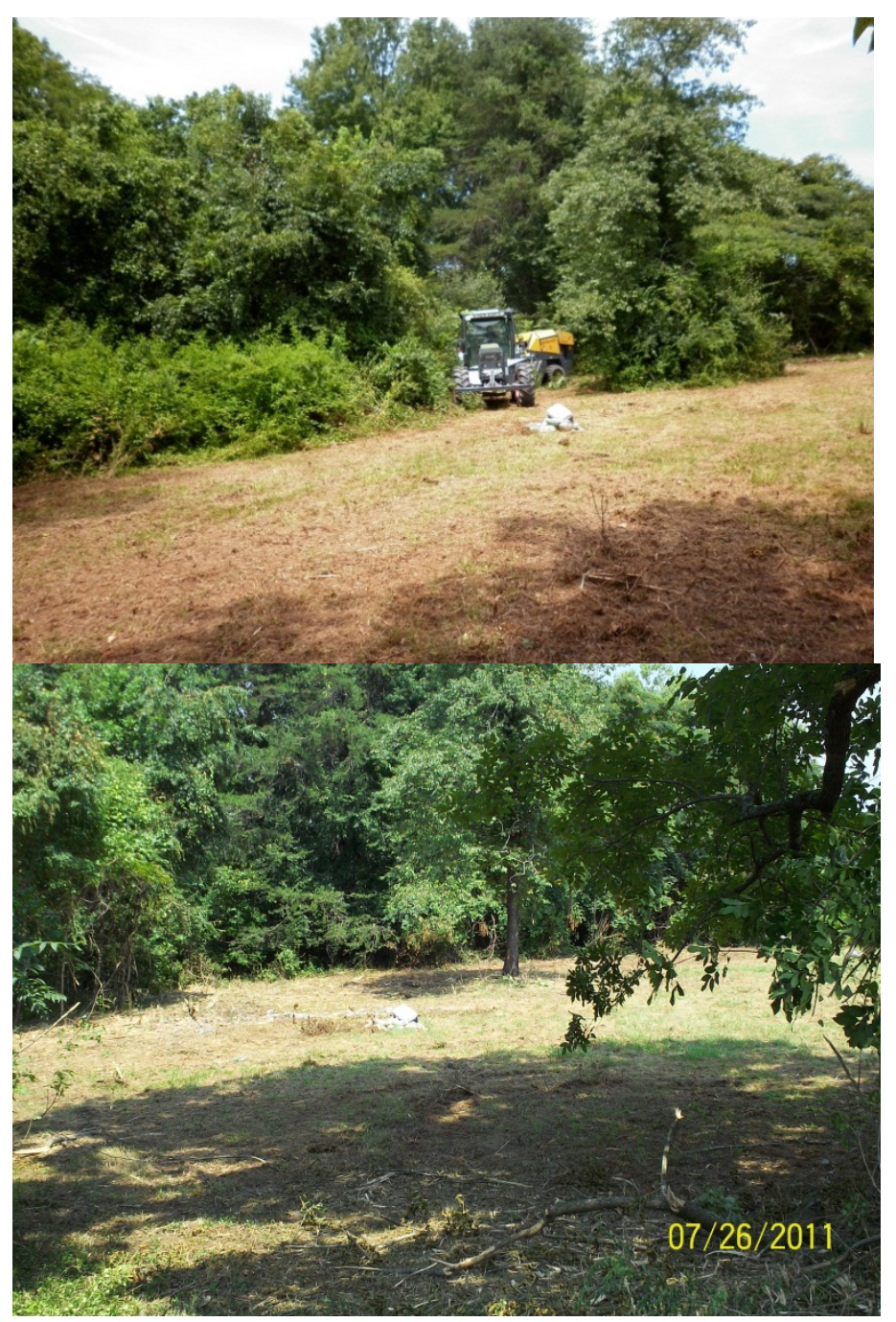

Figure 10. During (top) and after (bottom) bailing operations at the City of Oak Ridge.

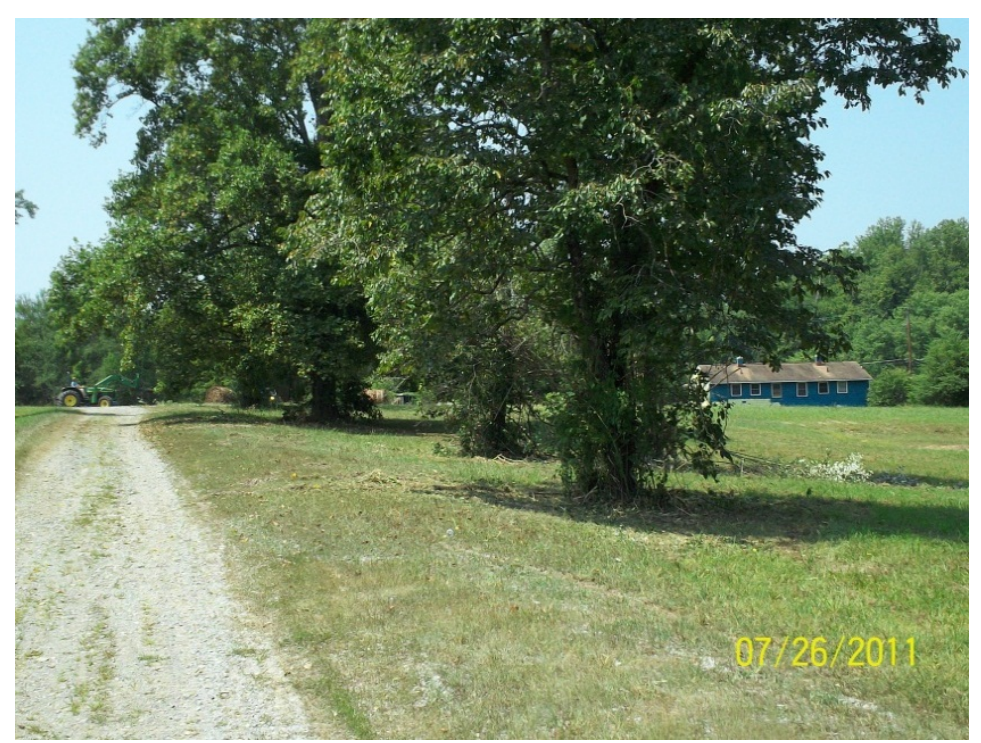

Figure 11. Underbrush removed following treatment with the BioBaler. 
Table 2. Bale weights observed on September 9th, 2011, 29 days after harvest. Bales were harvested from city land at the City of Oak Ridge on August 11th, 2011.

\begin{tabular}{ccc}
\hline Bale & Green lbs & $\begin{array}{c}\text { Dry lbs } \\
\text { (moisture content avg 37.5\%, } \mathrm{n}=5 \text { ) }\end{array}$ \\
\hline 1 & 1,060 & 663 \\
2 & 730 & 456 \\
3 & 984 & 615 \\
4 & 1,005 & 628 \\
5 & 996 & 623 \\
Average & 995 & 597 \\
\hline
\end{tabular}

\section{BIOBALER ECONOMIC ANALYSIS}

Here we calculate BioBaler harvest cost (\$/ton) as a component of total delivered cost (including feedstock price, transportation, and chipping). This is accomplished by dividing owning and operating (O\&O) costs (\$/hour) by harvest rate (tons/hour. Harvest rate can be estimated from the demonstration at Site \#3 of the UT Arboretum, and O\&O costs are adapted from an Anderson Group BioBaler System O\&O cost sheet.

The harvest trial on site \#3 at the UT Arboretum demonstrated a harvest rate of 7-12 bales/hour, with expected rates of 10-15 bales/hour on larger tracts that won't require frequent turning. While broad conclusions cannot be drawn from observations made at one site, site \#3 may reflect conditions found on roadside right-of-ways and 3-6-year-old regrowth that is seen on and around the ORR.

Assumptions in an O\&O cost sheet for equipment that might be included in a harvesting operation, including a tractor, BioBaler, bale forwarder, and a trailer are shown in Table 3. Operating costs in \$/hour for each of the four machines are shown at the bottom of Table 3.

Harvest and baling cost is the sum of columns 1 and 2, which reflect a tractor/BioBaler unit. The cost of extracting the bales from the field is the sum of columns 3 and 4 , which simulate a separate forwarder/trailer unit. It is estimated that one bale forwarder/trailer unit can extract at the same rate of production as 2 to 3 tractor/BioBaler units (Ted Pierce, Anderson Group, pers. comm. September $13^{\text {th }}$ 2011). We assume extraction (columns 3 and 4) O\&O costs are charged at 50\% for every hour of harvest and baling (columns 1 and 2) O\&O costs.

Harvest cost with the BioBaler is sensitive to harvest rate (bales/hour and tons/hour) (Figure 12). Harvest rate was observed to be 2-5 bales per hour at the City of Oak Ridge, and 7-12 bales per hour at the UT Arboretum. For comparison, Klepac and Rummer (2009) report 14.7 bales per hour over an extensive study in pine plantations in southeast Georgia, and Anderson Group reports 15-18 bales per hour in natural forests and 40 bales per hour under short-rotation woody crop plantations. We assume 10-15 bales per hour in this analysis. Harvest cost is calculated as: 


$$
C_{h}=\frac{\left(C_{b}+0.5 * C_{e}\right)}{\text { HarRate }^{*} \text { AvgBaleWt }}
$$

Equation 1

Where:

$C_{h}=$ Cost of harvest to field side.

$C_{b}=\mathrm{O} \& \mathrm{O}$ cost of baling/hour, including columns 1 and 2 of Table 3.

$C_{e}=\mathrm{O} \& \mathrm{O}$ cost of extracting/hour, including columns 3 and 4 of Table 3.

HarRate=Harvest rate of bales/hour (low of 10, high of 15).

AvgBaleWt=Average bale weight, (900 lbs at 37.5\% MC).

Applying Equation 1, harvest cost to field side is estimated to be in the range of $\$ 23.00$ to $\$ 34.00 /$ green ton under harvest rates of 15 and 10 bales/hour, respectively (37.5\% MC at time of weight) (Table 4). These costs are comparable to the $\$ 23.00$ to $\$ 24.00$ per green ton estimated by Klepac and Rummer (2009).

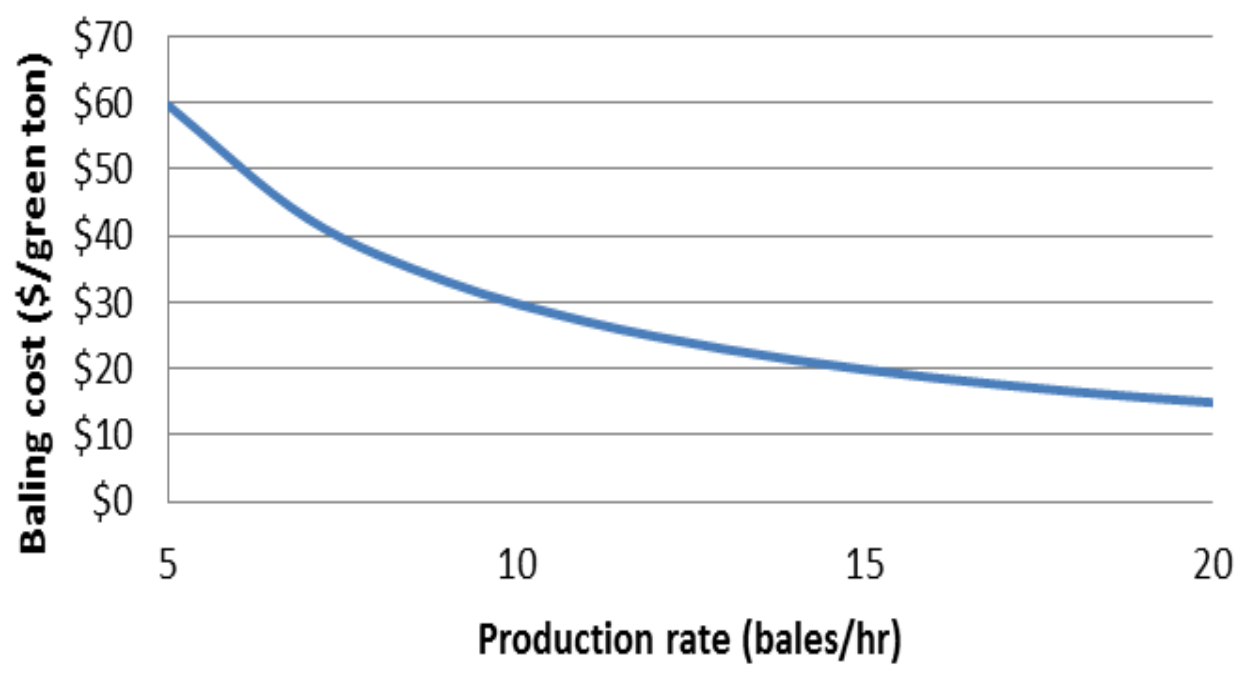

Figure 12. Baling cost (\$/green ton) as a function of production rate (bales/hour). Assumptions shown in Table 3 and Table 4. 
Table 3. Owning and operating costs for four pieces of equipment needed in a BioBale harvesting operation (provided by Anderson Group).

\begin{tabular}{|c|c|c|c|c|}
\hline & \multicolumn{2}{|c|}{ Harvest and baling } & \multicolumn{2}{|c|}{ Extraction } \\
\hline & Tractor & BioBaler & Bale forwarder & Bale trailer \\
\hline Replacement cost & $\$ 175,000.00$ & $\$ 140,000.00$ & $\$ 75,000.00$ & $\$ 20,000.00$ \\
\hline Life & 5 & 3 & 5 & 3 \\
\hline Scheduled days / year & 230 & 230 & 230 & 230 \\
\hline Scheduled hours per day & 8 & 8 & 8 & 8 \\
\hline Scheduled hours per life & 9200 & 5520 & 9200 & 5520 \\
\hline Residual value & $\$ 70,000.00$ & $\$ 35,000.00$ & $\$ 30,000.00$ & $\$ 0.00$ \\
\hline Depreciated cost & $\$ 105,000.00$ & $\$ 105,000.00$ & $\$ 45,000.00$ & $\$ 20,000.00$ \\
\hline Repair as $40 \%$ of Depreciation ${ }^{1}$ & $\$ 42,000.00$ & $\$ 52,500.00$ & $\$ 18,000.00$ & $\$ 10,000.00$ \\
\hline Interest rate & $10 \%$ & $10 \%$ & $10 \%$ & $10 \%$ \\
\hline Interest cost over life ${ }^{2}$ & $\$ 102,331.56$ & $\$ 52,783.28$ & $\$ 43,856.38$ & $\$ 3,232.37$ \\
\hline Damage insurance rate ${ }^{3}$ & $\$ 0.95$ & $\$ 0.95$ & $\$ 0.95$ & $\$ 0.95$ \\
\hline Insurance cost over life ${ }^{4}$ & $\$ 8,312.50$ & $\$ 3,990.00$ & $\$ 3,562.50$ & $\$ 570.00$ \\
\hline Operator wage per day & $\$ 96.00$ & $\$ 0.00$ & $\$ 96.00$ & $\$ 0.00$ \\
\hline Workman's comp rate ${ }^{5}$ & $\$ 33.94$ & $\$ 0.00$ & $\$ 33.94$ & $\$ 0.00$ \\
\hline Comp cost per day ${ }^{6}$ & $\$ 32.58$ & $\$ 0.00$ & $\$ 32.58$ & $\$ 0.00$ \\
\hline Social security cost ${ }^{7}$ & $\$ 7.65$ & $\$ 0.00$ & $\$ 7.65$ & $\$ 0.00$ \\
\hline Social security cost per day ${ }^{8}$ & $\$ 7.34$ & $\$ 0.00$ & $\$ 7.34$ & $\$ 0.00$ \\
\hline Operator cost per day & $\$ 135.93$ & $\$ 0.00$ & $\$ 135.93$ & $\$ 0.00$ \\
\hline Fuel consumed per day & 47.43 & 0.00 & 17.75 & 0.00 \\
\hline Fuel cost per gal & $\$ 3.25$ & $\$ 0.00$ & $\$ 3.25$ & $\$ 0.00$ \\
\hline Cost of Fuel Per Day & $\$ 154.15$ & $\$ 0.00$ & $\$ 57.69$ & $\$ 0.00$ \\
\hline Lubes and Oils Per Day & $\$ 15.42$ & $\$ 2.00$ & $\$ 5.77$ & $\$ 2.50$ \\
\hline \multicolumn{5}{|l|}{ Summary costs } \\
\hline Interest (\$/hour) ${ }^{9}$ & $\$ 11.12$ & $\$ 9.56$ & $\$ 4.77$ & $\$ 0.59$ \\
\hline Insurance $(\$ / \text { hour })^{10}$ & $\$ 0.90$ & $\$ 0.72$ & $\$ 0.39$ & $\$ 0.10$ \\
\hline Depreciation (\$/hour) $)^{11}$ & $\$ 11.41$ & $\$ 19.02$ & $\$ 4.89$ & $\$ 3.62$ \\
\hline Repair (\$/hour) $)^{12}$ & $\$ 4.57$ & $\$ 9.51$ & $\$ 1.96$ & $\$ 1.81$ \\
\hline Fuel \& lubes $(\$ / \text { hour })^{13}$ & $\$ 21.20$ & $\$ 0.25$ & $\$ 7.93$ & $\$ 0.31$ \\
\hline Operator cost $(\$ / \text { hour })^{14}$ & $\$ 16.99$ & \$- & $\$ 16.99$ & $\$-$ \\
\hline Total O\&O cost (\$/hour) ${ }^{15}$ & $\$ 66.17$ & $\$ 39.07$ & $\$ 36.92$ & $\$ 6.44$ \\
\hline
\end{tabular}

${ }^{1}$ Lifetime repair cost.

${ }^{2}$ Calculated as: (monthly payment of principle and interest*term*12 months/year)-replacement cost.

${ }^{3} \$ 0.95$ premium per $\$ 100.00$ of replacement cost.

${ }^{4}$ Calculated as: (replacement cost*0.95)/100*life.

${ }^{5}$ Per $\$ 100.00$ operator wage rate

${ }^{6}$ Calculated as: Workman's comp rate/100*Operator wage per day

${ }^{7}$ Per $\$ 100.00$ operator wage rate

${ }^{8}$ Calculated as: Social security cost $/ 100 *$ Operator wage per day

${ }^{9}$ Calculated as: Interest costs over life/scheduled hours per life

${ }^{10}$ Calculated as: Insurance costs over life/scheduled hours per life

${ }^{11}$ Calculated as: Depreciated cost over life/scheduled hours per life

${ }^{12}$ Calculated as: Repair as \% of depreciation/scheduled hours per life

${ }^{13}$ Calculated as: (Cost of fuel per day+Lubes and oils per day)/Scheduled hours per day

${ }^{14}$ Calculated as: Operator cost per day/Scheduled hours per day

${ }^{15}$ Calculated as: Sum of previous six summary costs 
Table 4. Combined operational costs and total harvest costs to field side (\$/ton).

\begin{tabular}{lrr}
\hline & Low yield & High Yield \\
\hline Harvest rate (bales/hour) & 10 & 15 \\
O\&O harvest and baling (tractor+BioBaler) $(\$ / \mathrm{hr})$ & $\$ 105.26$ & $\$ 105.26$ \\
O\&O extraction (forwarder+trailer) $(\$ / \mathrm{hr})$ & $\$ 43.36$ & $\$ 43.36$ \\
Combined O\&O (row 1 + 0.5*row 2) $(\$ / \mathrm{hr})$ & $\$ 126.94$ & $\$ 126.94$ \\
Utilization rate & $83 \%$ & $83 \%$ \\
Mobilization and De-mobilization & $4 \%$ & $4 \%$ \\
Combined Utilization rate & $79 \%$ & $79 \%$ \\
Adjusted combined O\&O (\$/hr) & $\$ 161.71$ & $\$ 161.71$ \\
Bale green weight (lbs/bale) & 900 & 900 \\
Harvest rate (green tons/hr) & 4.5 & 6.8 \\
Harvest cost, fieldside (\$/green ton) & $\$ 35.93$ & $\$ 23.96$ \\
Moisture content $(\%)$ & $38 \%$ & $38 \%$ \\
Harvest rate (dry tons/hr) & 2.8 & 4.2 \\
Harvest cost (\$/dry ton) & $\$ 57.50$ & $\$ 38.33$ \\
\hline
\end{tabular}

Sensitivity of BioBale harvest and forwarding cost to diesel assuming 900 green lbs/bale (37.5\% MC), and a harvest rate of 15 bales/hour is shown in Figure 13. A \$1.00 per gallon increase in the price of diesel translates to a $6 \%$ increase in the harvest and forwarding cost.

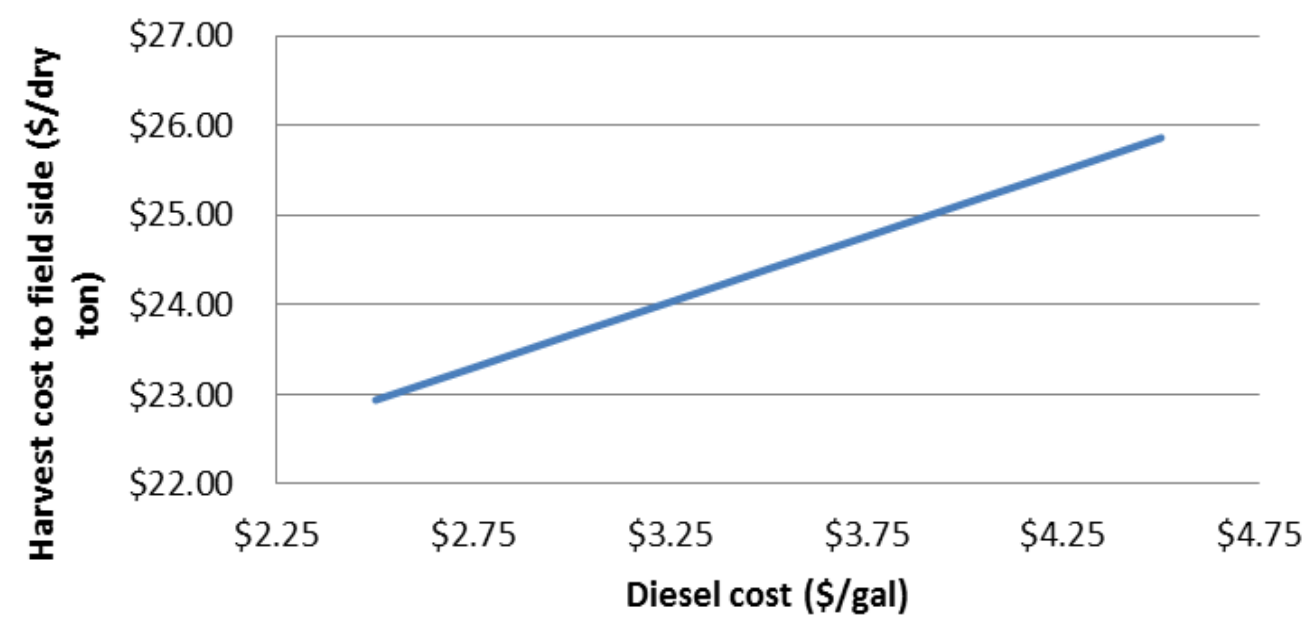

Figure 13. Sensitivity of BioBale harvest and forwarding cost to diesel cost assuming 900 green lbs/bale (37.5\% MC), and a harvest rate of 15 bales/hour. A $\$ 1.00 / g a l l o n$ increase in the price of diesel translates to a $6 \%$ increase in the harvest and forwarding cost.

\section{SUMMARY AND FUTURE RESEARCH}

Initial results suggest harvest cost to field side using the BioBaler is likely to be in the range of \$20.00-\$35.00 per green ton, with higher biomass volumes per acre increasing harvesting efficiency and decreasing cost. Transportation and chipping costs would add approximately $\$ 5.00$ and $\$ 3.00$ per green ton respectively, with total delivered price in the range of \$32.00$\$ 44.00$ per green ton. This assumes no payment is made for benefits achieved through vegetation control. However, the potential for payment for vegetation control exists based on 
the following examples.

ORNL, Tennessee Valley Authority (TVA), and land owners in the Oak Ridge area all pay for mowing and land clearing in the range of \$100-\$300 per acre. For example, land managers pay to thin stands, control vegetation under power lines, clear growth for replanting, and control invasive exotic species. Assuming a harvest rate of only 5 bales per acre, this would translate to a tipping fee, (i.e. negative cost or payment) of $\$ 30.00-\$ 60.00$ per bale or about $\$ 15.00$ - $\$ 30.00$ per green ton. Under this arrangement, about $50 \%$ to $100 \%$ of the BioBale harvest cost could be covered, resulting in an inexpensive feedstock source that turns a liability into a resource while generating local employment. This benefit could reduce costs to the range of $\$ 17.00-\$ 29.00$ per green ton or less (Table 5). Land clearing including vegetation removal may cost up to \$1,500/acre (Kevin Hoyt, UT Forest Resources Research and Education Center, pers com Sept $19^{\text {th }}, 2011$ ) indicating that payments for land clearing would more than offset BioBale harvesting costs in some scenarios.

Table 5. BioBaler cost summary table.

\begin{tabular}{lrr}
\hline & 10 Bales/hour & 15 Bales/hour \\
\hline Harvest rate (green tons/hour) (37.5\% MC) & 4.5 & 6.8 \\
Harvest cost (field side, \$/green ton) & $\$ 35.93$ & $\$ 23.96$ \\
Haul cost (\$/green ton) & $\$ 5.00$ & $\$ 5.00$ \\
Chipping cost (\$/green ton) & $\$ 3.00$ & $\$ 3.00$ \\
Total cost without tipping fee (\$/green ton) & $\mathbf{\$ 4 3 . 9 3}$ & $\mathbf{\$ 3 1 . 9 6}$ \\
Potential land clearing tipping fee (\$15-\$30 or more per green ton) & $\mathbf{\$ 1 5 . 0 0}$ & $\mathbf{- \$ 1 5 . 0 0}$ \\
Total cost with tipping fee (\$/green ton) & $\mathbf{\$ 2 8 . 9 3}$ & $\mathbf{\$ 1 6 . 9 5}$ \\
\hline
\end{tabular}

ORNL and surrounding ownerships invest resources in the control of invasive exotic species, such as autumn olive, privet, kudzu, and others. While unmanaged cutting can exacerbate problems with invasives, vegetation removal with a BioBaler might contribute to a holistic program of invasive control. For example, vegetation might be cut with the intention of herbiciding regrowth the following season, or herbicided sites could be cut back to facilitate access and/or establishment of native vegetation (Harry Quarles, pers. comm., July $16^{\text {th }}$ 2011). Any application of the BioBaler to control invasive exotic species should be integrated with existing ORR invasive control efforts.

Definitive conclusions on the economic viability of the BioBaler to sustainably produce feedstock for the steam plant cannot be drawn from a trial harvest of ten bales. However, these results suggest that innovative vegetation management strategies may be a win-win, providing environmental benefits while producing sustainable biomass. Synergistic relationships could be developed between the ORR, TVA, the University of Tennessee, and the forestry sector to produce biomass feedstock in ways that benefit the environment, convert a liability into an asset, generate local employment, and are viewed favorably by the public. Thus, further research is warranted to evaluate the economic viability and socioenvironmental sustainability of the BioBaler to contribute to the Steam Plant feedstock supply. Future research includes but is not limited to:

1. Identification of current ORR vegetation control operations and areas (acres) that could benefit from use of the BioBaler, including under power lines, near 
roads, as part of existing control programs of invasive exotic species, and in overstocked forest stands.

2. Same as \#1 above, but off-site in the Oak Ridge vicinity.

3. Evaluation of the spatial distribution, yield, and harvest frequency associated with the areas identified in \#1 and \#2, to evaluate potential supply operational strategies that might be applied.

4. Consideration of innovative alternative machine ownership strategies. For example, a BioBaler could be owned and operated privately, and be used to harvest small-diameter woody biomass on and off the ORR to maximize machine utilization.

5. Due diligence of economics and logistical implementation, including transportation, bale storage and BTU retention, and chipping operations.

6. Evaluation of business model options.

Feedback from industrial and non-industrial private forest landowners, the Tennessee Valley Authority, and local, state, and federal forestland managers at the BioBaler demonstration field day suggest that stakeholders may be interested in a wide range of applications of the BioBaler. Land-use objectives under these different ownerships will vary widely from wildlife habitat improvement to profit maximization. Given the broad scope of potential application, and given that various harvesting applications might be needed in the Oak Ridge area to cover costs of ownership of a BioBaler, we recommend a holistic assessment of potential biobaler application. 


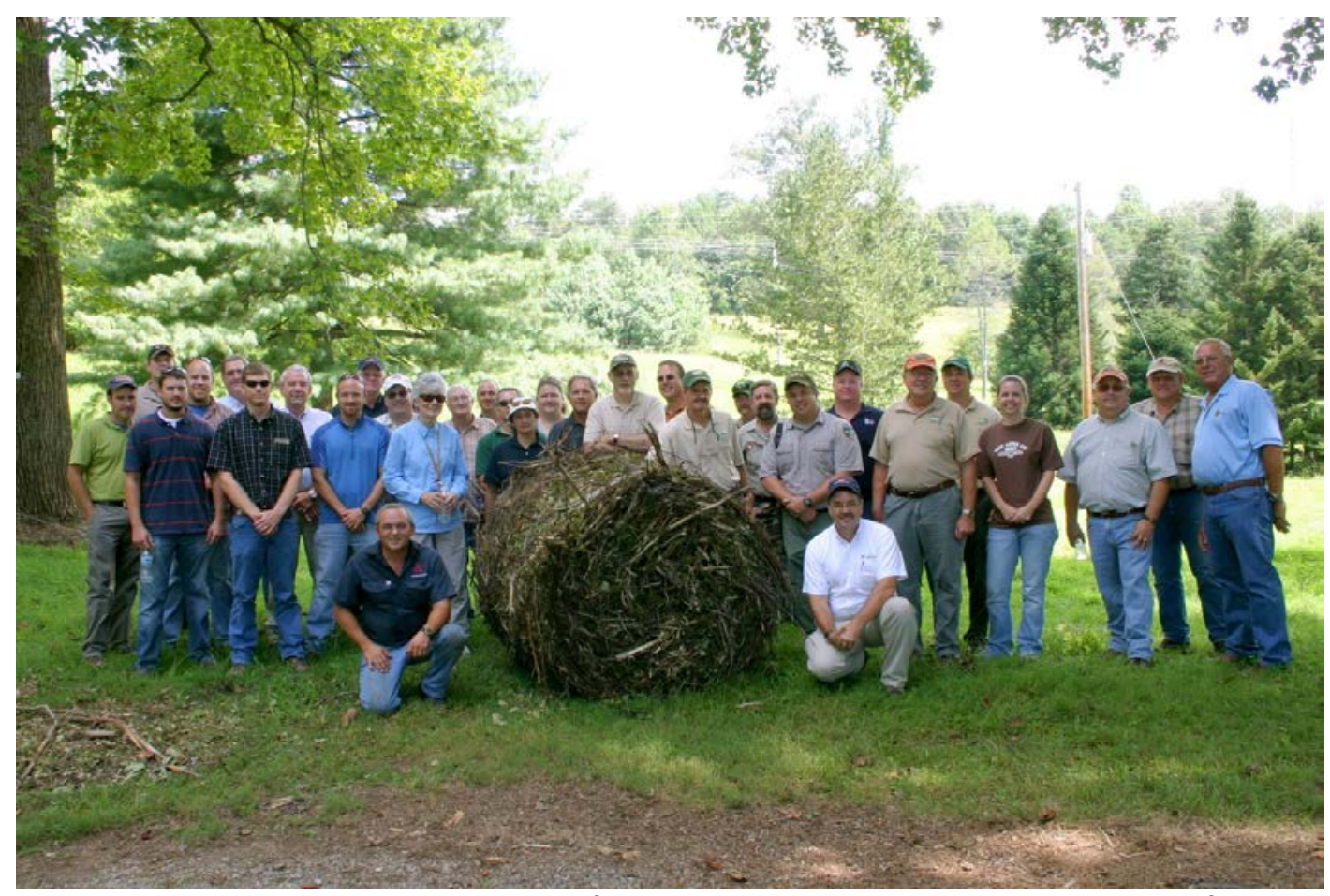

Figure 14. BioBaler demonstration participants from ORNL, the USDA Forest Service, TN Division of Forestry, Genera Energy, the University of Tennessee, and Domtar Paper. August 10th, 2011 at the UT Arboretum.

\section{ACKNOWLEDGEMENTS}

The BioBaler demonstration was made a success through collaboration with Kevin Hoyt, Richard Evans, and others at the University of Tennessee Forest Resources Research and Education Center (Arboretum); Josh Collins at the City of Oak Ridge Parks and Recreation, and Jack Suggs at the City of Oak Ridge Utilities; Tom King and Jose Hernandez of SuperTrak, Inc; and participants from ORNL, the USDA Forest Service, TN Division of Forestry, Genera Energy, the University of Tennessee, and Domtar Paper.

\section{REFERENCES}

Klepac, J, and B Rummer. 2009. Evaluation of the WB55 Biobaler for Baling Woody Biomass in a Forest Application. Paper read at 2009 National Convention of the Society of American Foresters, at Orlando, FL. 

APPENDIX - BIOBALE ANALYSIS RESULTS 
Table 6. Analysis results of BioBale biomass samples. Bales were harvested on August $10^{\text {th }}$, samples were taken on September $9^{\text {th }}$, sent to Twin Ports Testing on September $12^{\text {th }}$, and processed on September $14^{\text {th }}, 2011$. Samples A1-A5 were taken at the UT Arboretum, while samples C1-C5 were taken from the City of Oak Ridge.

\begin{tabular}{|c|c|c|c|c|c|c|c|c|c|c|c|c|c|}
\hline Sample Log No: & 11C2826 & 11C2827 & 11C2828 & 11C2829 & 11C2830 & 11C2831 & 11C2832 & 11C2833 & 11C2834 & 11C2835 & & & \\
\hline Sample Designation: & $\mathrm{A} 1$ & $\mathrm{~A} 2$ & $\mathrm{~A} 3$ & A4 & A5 & $\mathrm{C} 1$ & $\mathrm{C} 2$ & $\mathrm{C} 3$ & $\mathrm{C} 4$ & $\mathrm{C} 5$ & Max & Min & Average \\
\hline \%MC, received & 26.02 & 36.96 & 46.04 & 32.51 & 36.91 & 42.28 & 42.96 & 42.61 & 34.73 & 34.71 & 26.02 & 26.02 & 37.57 \\
\hline$\%$ ash, dry weight & 2.62 & 1.85 & 1.78 & 2.32 & 3.42 & 4.5 & 2.47 & 1.59 & 2.37 & 1.37 & 1.37 & 1.37 & 2.43 \\
\hline$\%$ ash, received & 1.94 & 1.17 & 0.96 & 1.57 & 2.16 & 2.6 & 1.41 & 0.91 & 1.55 & 0.89 & 0.89 & 0.89 & 1.52 \\
\hline$\%$ Volatile matter, dry & 80.44 & 88.03 & 97.47 & 77.88 & 77.66 & 92.86 & 52.23 & 22.59 & 42.84 & 42.08 & 22.59 & 22.59 & 67.41 \\
\hline$\%$ Volatile matter, received & 59.51 & 55.5 & 52.6 & 52.56 & 48.99 & 53.6 & 29.79 & 12.97 & 27.96 & 27.48 & 12.97 & 12.97 & 42.10 \\
\hline$\%$ Fixed C, DW & 16.95 & 10.12 & 0.75 & 19.8 & 18.92 & 2.64 & 45.3 & 75.81 & 54.78 & 56.55 & 0.75 & 0.75 & 30.16 \\
\hline$\%$ Fixed C, GW & 12.54 & 6.38 & 0.4 & 13.36 & 11.94 & 1.53 & 25.84 & 43.51 & 35.76 & 36.92 & 0.4 & 0.4 & 18.82 \\
\hline \% S DW & 0.03 & 0.02 & 0.03 & 0.06 & 0.08 & 0.05 & 0.14 & 0.11 & 0.04 & 0.02 & 0.02 & 0.02 & 0.06 \\
\hline$\%$ S GW & 0.02 & 0.01 & 0.02 & 0.04 & 0.05 & 0.03 & 0.08 & 0.06 & 0.02 & 0.02 & 0.01 & 0.01 & 0.04 \\
\hline Gross heating value, moisture and ash free & 8,599 & 8,538 & 8,517 & 8,728 & 8,874 & 8,883 & 8,792 & 8,518 & 8,758 & 8,579 & 8,517 & 8,517 & 8,679 \\
\hline Gross heating value, moisture free & 8,374 & 8,380 & 8,365 & 8,526 & 8,571 & 8,483 & 8,575 & 8,382 & 8,550 & 8,462 & 8,365 & 8,365 & 8,467 \\
\hline Gross heating value, as received & 6195 & 5283 & 4514 & 5754 & 5407 & 4897 & 4891 & 4810 & 5581 & 5525 & 4514 & 4514 & 5285.70 \\
\hline \% C moisture free & 48.98 & 47.82 & 47.77 & 47.6 & 47.82 & 48.2 & 48.06 & 48.1 & 48.9 & 48.42 & 47.6 & 47.6 & 48.17 \\
\hline$\% \mathrm{C}$ as received & 36.24 & 30.15 & 25.78 & 32.12 & 30.17 & 27.82 & 27.41 & 27.6 & 31.92 & 31.61 & 25.78 & 25.78 & 30.08 \\
\hline$\% \mathrm{H}$ moisture free & 5.73 & 5.75 & 5.76 & 5.67 & 5.61 & 5.66 & 5.72 & 5.8 & 5.62 & 5.86 & 5.61 & 5.61 & 5.72 \\
\hline$\% \mathrm{H}$ as received & 4.24 & 3.62 & 3.11 & 3.83 & 3.54 & 3.27 & 3.26 & 3.33 & 3.67 & 3.83 & 3.11 & 3.11 & 3.57 \\
\hline$\% \mathrm{~N}$ moisture free & 0.32 & 0.19 & 0.03 & 0.33 & 0.51 & 0.41 & 0.22 & 0.03 & 0.48 & 0.13 & 0.03 & 0.03 & 0.27 \\
\hline$\% \mathrm{~N}$ as received & 0.24 & 0.12 & 0.02 & 0.22 & 0.32 & 0.24 & 0.13 & 0.02 & 0.31 & 0.08 & 0.02 & 0.02 & 0.17 \\
\hline$\% O$ moisture free & 42.32 & 44.37 & 44.63 & 44.02 & 42.55 & 41.19 & 43.39 & 44.37 & 42.59 & 44.2 & 41.19 & 41.19 & 43.36 \\
\hline$\% \mathrm{O}$ as received & 31.31 & 27.97 & 24.08 & 29.71 & 26.85 & 23.77 & 24.75 & 25.46 & 27.8 & 28.86 & 23.77 & 23.77 & 27.06 \\
\hline
\end{tabular}

